\title{
cGMP-dependent kinase I supports formation of associative fear memory and long-term potentiation in the lateral amygdala Cindy Paul*1, Pascal Weinmeister ${ }^{1}$, Robert Feil ${ }^{2}$, Franz Hofmann ${ }^{1}$ and Thomas Kleppisch ${ }^{1}$
}

Address: ${ }^{1}$ Institut für Pharmakologie und Toxikologie, TU München, München, Germany and 2Interfakultäres Institut für Biochemie, Eberhard Karls Universität Tübingen, Tübingen, Germany

Email: Cindy Paul* - Paul@ipt.med.tu-muenchen.de

* Corresponding author

from $3^{\text {rd }}$ International Conference on cGMP Generators, Effectors and Therapeutic Implications

Dresden, Germany. 15-17 June 2007

Published: 25 July 2007

BMC Pharmacology 2007, 7(Suppl I):P46 doi:I0.1186/147I-22I0-7-SI-P46

This abstract is available from: http://www.biomedcentral.com//47I-22/0/7/SI/P46

(C) 2007 Paul et al; licensee BioMed Central Ltd.

Nitric oxide (NO) and cGMP have been reported to modulate memory consolidation of Pavlovian fear conditioning and long-term potentiation (LTP) of synaptic transmission in the amygdala. The cGMP-dependent protein kinases, cGKI and cGKII, representing universal effectors in the NO/cGMP signalling cascade are both expressed in the amygdala and their function for amygdala-dependent fear conditioning and synaptic plasticity remains to be elucidated. Associative fear learning is thought to rely on synaptic plasticity in various inputs to the lateral amygdala. We initially examined LTP in the amygdala of wild type and cGKI-/- mice using extracellular recordings. Mutant mice showed reduced LTP in the cortical input to the lateral amygdala (see Figure 1). Behavioural analysis in cGKI null mutants (cGKI-/-) is obstructed by their premature death resulting from severe smooth muscle dysfunction. Differently, cGK-deficient mice live to adulthood when the expression of cGKI is rescued selectively in smooth muscle cells. We used this mouse model (cGKI rescue) to examine whether the impairment of synaptic plasticity due to the lack of cGKI is paralleled by a defect of amygdala-dependent learning. Therefore, we studied amygdala-dependent cued fear and contextual fear behaviour in wild type and rescue mice. Freezing to a tone previously conditioned with a foot shock was significantly reduced in cGKI rescue mice compared with control suggesting an impairment of the toneshock association (see Figure 2). Freezing in the condi- tioning environment was not different in control and cGKI rescue mice indicating that contextual fear memory was normal.

\section{Conclusion}

Inferior performance in fear conditioning of cGKI-deficient mice demonstrate a critical role of the cGKI isoform

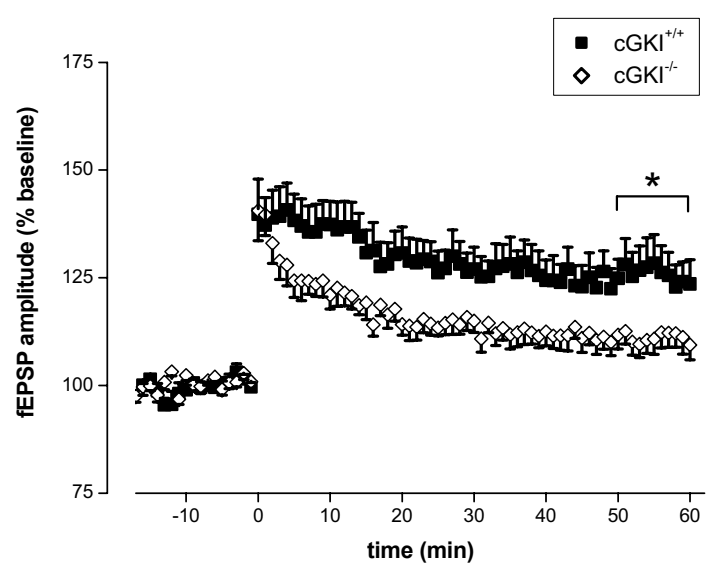

Figure I

cGKI-deficient mice show reduced long-term potentiation in the cortical input of the lateral amygdala. 


\section{Protocol A}

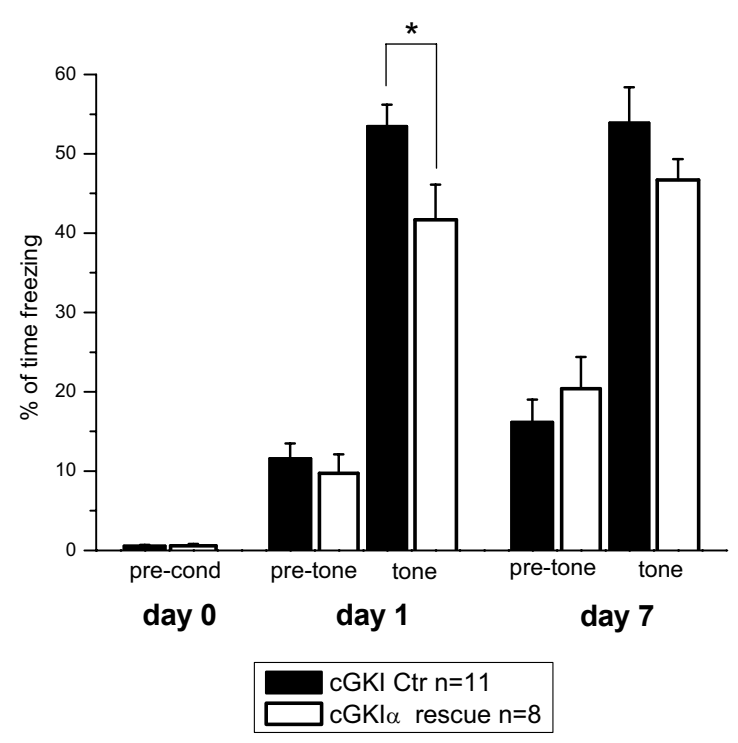

\section{Protocol B}

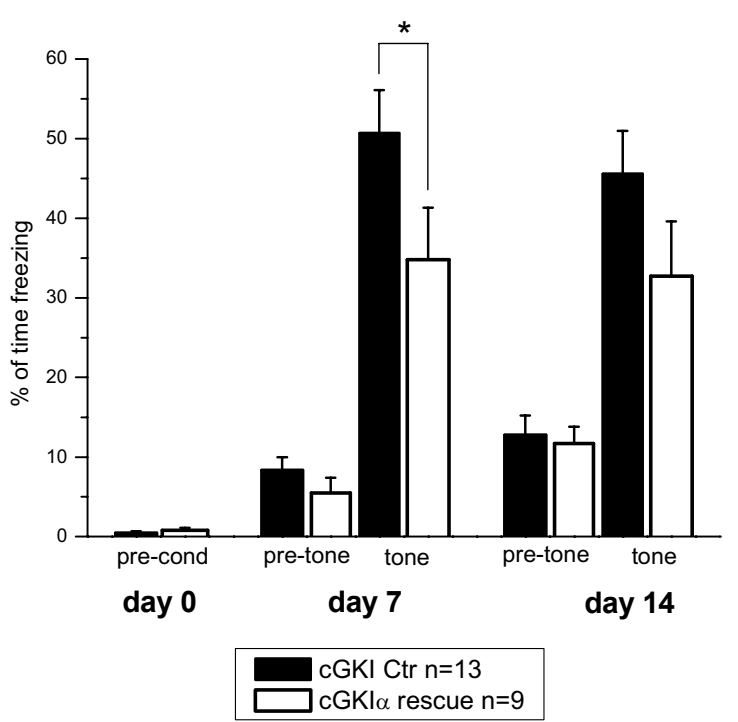

Figure 2

Freezing to the conditioned tone is reduced in CGKI-deficient mice compared to control on day I with protocol A (day $0 \rightarrow$ day $\mathrm{I} \rightarrow$ day 7 ) and also on day 7 with protocol B (day $0 \rightarrow$ day $7 \rightarrow$ day 14 ).

for associative learning likely related to mechanisms supporting memory consolidation. Moreover, reduced LTP of cGKI-- mice show that synaptic plasticity in the lateral amygdala is supported by cGKI.
Publish with Biomed Central and every scientist can read your work free of charge

"BioMed Central will be the most significant development for disseminating the results of biomedical research in our lifetime. "

Sir Paul Nurse, Cancer Research UK

Your research papers will be:

- available free of charge to the entire biomedical community

- peer reviewed and published immediately upon acceptance

- cited in PubMed and archived on PubMed Central

- yours - you keep the copyright

Submit your manuscript here:

http://www.biomedcentral.com/info/publishing_adv.asp
BioMedcentral 